International Journal of Management Science and Business Administration

Volume 3, Issue 3, March 2017, Pages 33-38

DOI: $10.18775 /$ ijmsba.1849-5664-5419.2014.33.1004

URL: http://dx.doi.org/10.18775/ijmsba.1849-5664-5419.2014.33.1004

\title{
Cost Accounting and Financial Health: Analysis of Cost Reduction Policy Effect in Selected Enterprises of Metallurgy Industry in Uzbekistan
}

\author{
Nodira Abdusalomova \\ Researcher of Tashkent State University of Economics, Tashkent, Uzbekistan
}

\begin{abstract}
Cost accounting is an emerging trend of business accounting in developing economies. Deep-in-root accounting reforms and advances in business climate involve the cost accounting techniques which could embrace technological, market and financial healthiness factors of a business. As a developing economy, Uzbekistan has been reforming accounting system and developing the coverage of accounting in providing financial data in all sectors. Moreover, the government is ensuring cost reduction initiatives to stabilize the price volatility and mitigate the demand shock for particular enterprises. Metallurgic industry, in this line, has been benefiting from this initiative and reducing the output cost within the established target. Cost reduction policy is directly influencing on the cost accounting and costing methods of metallurgic industry enterprises. Consequently, a need for introduction of modern cost accounting techniques to the accounting system has been emerging as a part of accounting system reform. This article examines the relevance of cost accounting by analyzing the effect of cost reduction policy on financial health of selected metallurgy industry enterprises. When it comes to methodology, it was chosen to apply Enyi's solvency model, which evaluate how the firm gets solvency and this model contains four prime steps.
\end{abstract}

Keywords: Cost accounting, Cost reduction policy, Metallurgy industry, Uzbekistan.

\section{Introduction}

Contemporary changes in the organization and technology of manufacturing operations have caused the traditional, direct-labor focused, cost accounting system to be a less useful summary of a company's manufacturing operations (Kaplan, 1986). Recent changes in marketing strategies, competition and production environments, and consequent changes in cost structures, have been argued as imposing pressure for change on current cost accounting (Lukk and Granlund, 1996). Relentless technology developments and innovative production facilities are making the accounting system to be flexible to adopt the changes, if a firm wants to stay in the market. As Kaplan concerned, accounting system is lagging behind the costing and cost accounting due to changing face of the market and technology which can influence directly on product cost and price. All accounting standards still have remained incapable of offering flexible cost-accounting methods which can be exploited in all industries. Admittedly, developed economies possess advanced business environment which equipped with sound financial management and accounting practices. Their TNCs and MNCs transferred their experience to affiliates and subsidiaries operating in developing economies with a limited scope of application due to structural barriers. Mismatch in accounting methods and reporting procedures pose structural difficulties for introducing cost accounting at least in the subsidiary firm.

Developing and transition economies regularly undergo structural reforms in different wings of their economies in order to keep pace with developments in the international economic community. Expansion of business sector and the creation of international investment environment attracted the interest of their governments to adopt business-related changes to have common properties with international practice. Tax and accounting systems were the primary area of reform for ensuring simplified and softer taxation and reporting systems. Particular group of developing economies adopted International Accounting Standards full-fledged and adjusted their accounting system in full consistency. However, transition economies faced the biggest challenge - economic reforms from the roots to the top which can be 
assumed as a new history of accounting evaluation in the economy. Developing countries who did not undergo communist system have adopted international accounting practices, including cost accounting smoothly with some piloting programs thanks to their market psychology and business sense. Countries transiting from planned to market economy had to change not only accounting system, but also business structure and people's views towards ownership. Separation of public, private and individual property, cancellation of absolute public ownership, introduction of business and corporate structures required new accounting policy which did not rely on former public sector experience. Therefore, countries preferred to adopt on gradual basis to ensure a smooth and a less risky way, and demanded for an accurate method of recognizing expenditure and income to evaluate private profit and tax liabilities.

As a transition and rapidly growing economy, Uzbekistan also opted for gradual adoption of accounting principles to eliminate the gaps in accounting competency. Since 1992, Uzbekistan developed the accounting system and eliminated nearly all the Soviet inherited accounting system elements. Cost accounting remained as an untouched area of accounting reform despite its current importance for business and investment environment. Although the government adopted national standards, regulations and instructions, a solid, separate and comprehensive cost accounting method has not been enforced yet. From 2012, the government has been lowering product net cost to boost competitiveness in some industries, which can pave a platform for full-fledged adoption of cost accounting principles. This article studies the possibilities and perspectives of cost accounting developments, and empirically analyzes the impact of cost reduction policy on financial health of selected heavy industry firms.

\section{Literature Review}

Cost accounting has been a hot topic of discussions in research, business and policymaking since early $19^{\text {th }}$ century. However, there is a historical evidence of cost accounting for management purposes in 1773 by Spanish Royal Tobacco Factory to minimize tobacco theft within factory by employees. Cost accounting was a disciplinary regime for employees who were working in the factory and dealing with tobacco. Cost accounting helped employers to conduct surveillance and monitoring over raw material security. The first theoretical efforts to adjust cost accounting practice were made by Brogdan and Taylor in 1950. They studied costing of labor and their productivity by dollarization of each activity and comparing them with proposed criterion. They offered a criterion to monitor the value personnel created and the cost they might incur. In 1972, Dearden examined the opportunities and prerequisites of introducing modern cost accounting practices to serve industries after pointing out that their cost accounting techniques were absolutely outdated and inefficient, as it could not provide satisfactory information about cost, profit and financial health of service industries. Dearden revealed the failing aspects and weaknesses of traditional cost accounting techniques and described a unique costing system for service industry enterprises. In 1981, Johnson studied the evolution and history of modern cost accounting. His studies suggested that history of cost accounting traced back to the industrial revolution occurred in the $1850 \mathrm{~s}$, when industrial economist began capital-saving production practices through technological development. He comparatively examined traditional and evolving cost accounting practices and explained the driving factors of change. Cancelling the traditional costing and introducing more modern approach has been debated since 1986, when Kaplan published his article dedicated to outdated cost accounting practices. In his paper, Kaplan criticized the modernity level of cost accounting practices, since the organizational structure of firms developed via innovations, while their cost accounting system could not keep pace with changes and remained closed for innovative approach. One year later, in 1987, Johnson and Kaplan published another paper dedicated to the critique of lagged cost accounting practices as a logical continuation and research support of their previously published paper. In 1991, Hopper and Armstrong argued that in technology revolution era, which began in the 1930s, cost accounting was not a consequence of technological or scientific development, but rather derived from firm's its own attempts to control labor. In their assumptions, cost accounting has been an agreement with labor and corporations to support monopoly pricing, favorable production and employment patterns. They admitted that in modern business, those tensions abandoned and cost accounting became a new tool for productivity control.

\section{Statement of the Problem}

After dissolution, former USSR inherited deep implications in the economy of all member states with high rate of poverty, unemployment and a large fiscal gap. Early independence period marked with radical reforms to get rid of the elements of planned economy and making radical changes in ownership, business, and industrial structure. Ownership reform was the first and the most important step in adopting market economy principles and restructuring the economy. 
The introduction of private ownership and creation of a business environment, which was strictly prohibited in the Soviet period, led to structural changes in the accounting system. Accounting reform started with the adoption of Production Cost Regulation which was a guide for accountant's business finance, tax accounting, and income statement preparation. In 1994, Chart of Accounts was adopted to both public and private sector to implement all accounting, reporting and auditing activity with modern methods of report preparation and cost calculations. In 1996, a separate fully-formed legislative act - Law on Accounting was adopted, despite it has several elements in transitional character. From 1998, National Accounting Standards were enforced as a set of instructions and guides for accountants. In these steps, probably sufficiently strong foundations for cost accounting were put, but any solid applications or instructions were not proposed. In literature, cost accounting may be considered as "a specialized branch of accounting which involves classification, accumulation, assignment and control of costs. But in our local practice, cost accounting seen as a part of management accounting and often overlooked without knowing its relevance and importance in taxation, profit maximization and decision-making processes. The government launched cost reduction policy in key industries of domestic economy, which directly influences on the cost, profit and tax aspects of enterprises operating in these industries. Consequently, cost reduction policy shows direct and collateral effect on the financial health of enterprises.

\section{Methodology}

Cost accounting is widespread, but less empirically analyzed branch of accounting. Adoption of cost accounting principles or a cost-related decision may have an effect on profitability, efficiency, and stability of a firm. The firm may have larger market share due to competitive price and may lose some profit due to lowered cost if they set lower profit margin. Eventually, a firm may get financial stronger or weaker. In this paper, we analyze the impact of costrelated decision in firm's financial health the sample of 12 heavy industry enterprises that began reducing the cost in 2014 on an annual basis under government's competitiveness support initiative.

We apply Enyi's relative solvency ratio model to examine the effect of cost reduction policy in firm's financial health. This model assesses how a firm gets solvent in a particular period. It has a similarity with Altman's bankruptcy prediction model which evaluates the financial distress in a firm in the given time and predicts the distance to default within two years. In Enyi's model, the financial health of a firm is analyzed in four main steps.

The first step is the calculation of Mark-up ratio (MUR) - measure of the ability of company management to cover the costs and maximize profit.

$$
M U R=P B T / T O C(1)
$$

Here, PBT - profit before tax, TOC - total operating cost.

The second step is the calculation of Operational Break Even Point (OBEP), in which financial stance of a firm in which firms earns the adequate income to cover all attributable cost. In OBEP, a firm makes equal income to the cost it incurred and become loss-free.

$$
O B E P=\frac{(1+M U R)}{(2 * M U R)}(2)
$$

Working capital required (WCR) -a measure of capital adequacy in a firm.

$$
W C R=(T O C / 52) * O B E P(3)
$$

Relative Solvency Ratio (RSR) - a measure of firm's liquidity indicator in terms of availability of adequate working capital for cumulative demands for covering the cost of further activity and losses. It reflects the likelihood of insolvency and stage of insolvency.

Here, AWC - available working capital.

$$
R S R=A W C / W C R(4)
$$

Chance of insolvency (COI) - probabilistic measurement of insolvency likelihood, fluctuates between 0 and 1 . If COI is equal to 0 , company is sound and solvent. If $\mathrm{COI}$ is equal around 1, a firm is bankrupt and insolvent.

$$
C O I=1-R S R(5)
$$


Table 1: Interpretation table of relative solvency ratio and choice of insolvency

\begin{tabular}{|l|l|l|}
\hline RSR & COI & Interpretation \\
\hline 0 & 1 & Firm is bankrupt \\
\hline 0.01 & $0.99-0.75$ & Firm is insolvent and going bankrupt. \\
\hline $0.26-0.50$ & $0.74-0.50$ & Firm is technically insolvent \\
\hline $0.51-0.75$ & $0.49-0.25$ & Firm has poor financial health \\
\hline $0.76-0.99$ & $0.24-0.01$ & Company has fair financial health \\
\hline 1.0 and above & 0 and less than 0 & Company is financially healthy/solvent \\
\hline
\end{tabular}

\section{Data and Analysis}

At the first step, we calculate mark-up ratio for selected enterprises. It reflects the profitability of an enterprise through a ratio of profit before tax and total operating cost. Besides it reflects the weighted dynamics of profit and cost.

Table 2: Mark-up ratio of selected enterprises in 2012-2015

\begin{tabular}{|l|l|l|l|l|}
\hline Company & $\mathbf{2 0 1 2}$ & $\mathbf{2 0 1 3}$ & $\mathbf{2 0 1 4}$ & $\mathbf{2 0 1 5}$ \\
\hline Ikkikoramet & 0,0093 & 0,0117 & 0,0027 & 0,0037 \\
\hline Tashkentvtorchermet & 0,0059 & 0,0030 & 0,0376 & 0,0094 \\
\hline Djizakvtorchermet & 0,0038 & 0,0038 & 0,0203 & 0,0035 \\
\hline Samarkand VCHM & 0,0006 & 0,0014 & 0,0009 & 0,0010 \\
\hline Surkhandarya VCHM & 0,0025 & 0,0015 & 0,0012 & 0,0026 \\
\hline Namangan Vtorchermet & 0,0022 & 0,0091 & 0,0021 & 0,0028 \\
\hline KarshiVtorchermet & 0,0150 & 0,0031 & 0,0199 & 0,0016 \\
\hline Bukhara VCHM & 0,0008 & 0,0073 & 0,0362 & 0,0072 \\
\hline Andijanvtorchermet & 0,0791 & 0,0016 & 0,0068 & 0,0032 \\
\hline Karakalpak VCHM & 0,0321 & 0,0031 & 0,0017 & 0,0020 \\
\hline SurkhonVtorchermet & 0,0062 & 0,0026 & 0,0075 & 0,0025 \\
\hline Khorazm VCHM & 0,0173 & 0,0006 & 0,0014 & 0,0147 \\
\hline Guliston IKM & 0,0052 & 0,0041 & 0,0022 & 0,0129 \\
\hline Total & $\mathbf{0 , 0 1 6 6}$ & $\mathbf{0 , 0 0 4 5}$ & $\mathbf{0 , 0 1 5 4}$ & $\mathbf{0 , 0 0 5 1}$ \\
\hline
\end{tabular}

Operational break-even point for enterprises shows the neutral point of financial stance which shows the company performing without losses and covers the incurred cost. For selected 13 enterprises and total for metal processing industry, mark-up ratio fluctuated in the given time period.

Table 3: Operational break-even point for selected enterprises in 2012-2015

\begin{tabular}{|l|l|l|l|l|}
\hline Company & $\mathbf{2 0 1 2}$ & $\mathbf{2 0 1 3}$ & $\mathbf{2 0 1 4}$ & $\mathbf{2 0 1 5}$ \\
\hline Ikkikoramet & 54,135 & 43,111 & 183,424 & 133,906 \\
\hline Tashkentvtorchermet & 85,147 & 165,769 & 13,811 & 53,676 \\
\hline Djizakvtorchermet & 131,267 & 133,743 & 25,130 & 142,572 \\
\hline Samarkand VCHM & 848,481 & 358,011 & 566,436 & 490,739 \\
\hline Surkhandarya VCHM & 197,407 & 340,471 & 426,042 & 192,768 \\
\hline Namangan Vtorchermet & 230,175 & 55,480 & 241,178 & 180,526 \\
\hline KarshiVtorchermet & 33,826 & 160,488 & 25,568 & 312,133 \\
\hline
\end{tabular}


Nodira Abdusalomova

Cost Accounting and Financial Health: Analysis of Cost Reduction Policy Effect in Selected Enterprises of Metallurgy Industry in Uzbekistan

\begin{tabular}{|l|l|l|l|l|}
\hline Bukhara VCHM & 619,561 & 69,086 & 14,328 & 69,818 \\
\hline Andijanvtorchermet & 6,825 & 310,520 & 74,287 & 154,936 \\
\hline Karakalpak VCHM & 16,095 & 159,619 & 298,865 & 252,217 \\
\hline SurkhonVtorchermet & 81,378 & 191,804 & 66,918 & 203,991 \\
\hline Khorazm VCHM & 29,357 & 838,118 & 366,442 & 34,628 \\
\hline Guliston IKM & 96,643 & 123,079 & 229,794 & 39,245 \\
\hline Total & $\mathbf{3 0 , 6 3 2}$ & $\mathbf{1 1 2 , 0 2 4}$ & $\mathbf{3 3 , 0 0 8}$ & $\mathbf{9 9 , 1 0 7}$ \\
\hline
\end{tabular}

Required working capital is the key indicator of capital adequacy for an enterprise. Working capital is the difference between current assets and current liabilities. Enterprises sometimes face the lack of working capital in production process. It results in temporary loss of production capacity. Required volume of working capital for staying solvent and operating without losses can be seen in Table 3.

Table 4: Required working capital for selected enterprises in 2012-2015, in thousand UZS

\begin{tabular}{|l|l|l|l|l|}
\hline Company & $\mathbf{2 0 1 2}$ & $\mathbf{2 0 1 3}$ & $\mathbf{2 0 1 4}$ & $\mathbf{2 0 1 5}$ \\
\hline Ikkikoramet & 296585 & 249691,5 & 256338,6 & 348796,8 \\
\hline Tashkentvtorchermet & 381256 & 421818,3 & 447905,1 & 531056,9 \\
\hline Djizakvtorchermet & 47193 & 55858,28 & 64306,22 & 79278,26 \\
\hline Samarkand VCHM & 101948 & 116332,9 & 133025,3 & 133207,3 \\
\hline Surkhandarya VCHM & 70554 & 78373,81 & 78326,18 & 110678,5 \\
\hline Namangan Vtorchermet & 90140,1 & 84107,68 & 103372,6 & 113193,3 \\
\hline KarshiVtorchermet & 131137 & 126304,1 & 121596,5 & 172531,5 \\
\hline Bukhara VCHM & 110890 & 127447,7 & 147044,7 & 146952,1 \\
\hline Andijanvtorchermet & 186660 & 202590,4 & 217478 & 225518,3 \\
\hline Karakalpak VCHM & 119354 & 114677 & 137006,6 & 215010,1 \\
\hline SurkhonVtorchermet & 21274,1 & 18734,09 & 16115,66 & 28982,41 \\
\hline Khorazm VCHM & 217995 & 83908,51 & 96339,01 & 104191,7 \\
\hline Guliston IKM & 40378,2 & 37745,02 & 40068,12 & 5703,355 \\
\hline Total & $\mathbf{1 6 2 1 6 8 0}$ & $\mathbf{1 7 1 7 5 8 9}$ & $\mathbf{1 8 5 8 9 2 6}$ & $\mathbf{2 2 5 8 5 5 7}$ \\
\hline
\end{tabular}

Relative solvency ratio assesses the enterprise's ability to meet financial liabilities and adequacy of capital to operate without losses. In the sample of selected 13 enterprises and cumulative data for the industry, cost reduction policy of the government influenced positively. Despite the unavailability of common conclusion for all selected enterprises, comparison of solvency between first and last years of the selected period suggests that unevenly distributed effect led to an increase in overall solvency status in the industry.

Table 5: Relative solvency ratio of selected enterprises

\begin{tabular}{|l|l|l|l|l|}
\hline Company & $\mathbf{2 0 1 2}$ & $\mathbf{2 0 1 3}$ & $\mathbf{2 0 1 4}$ & $\mathbf{2 0 1 5}$ \\
\hline Ikkikoramet & 0,91 & 0,95 & 0,99 & 1,00 \\
\hline Tashkentvtorchermet & 0,92 & 0,96 & 1,01 & 1,00 \\
\hline Djizakvtorchermet & 0,86 & 0,91 & 0,97 & 0,99 \\
\hline Samarkand VCHM & 0,78 & 0,85 & 0,94 & 0,97 \\
\hline Surkhandarya VCHM & 0,81 & 0,91 & 0,94 & 0,94 \\
\hline Namangan Vtorchermet & 0,87 & 0,88 & 0,95 & 1,02 \\
\hline KarshiVtorchermet & 0,70 & 0,89 & 0,94 & 0,96 \\
\hline Bukhara VCHM & 0,83 & 0,82 & 0,89 & 0,97 \\
\hline
\end{tabular}




\begin{tabular}{|l|l|l|l|l|}
\hline Andijanvtorchermet & 0,92 & 0,96 & 0,95 & 1,01 \\
\hline Karakalpak VCHM & 0,91 & 0,93 & 0,96 & 1,00 \\
\hline SurkhonVtorchermet & 0,88 & 0,97 & 0,98 & 0,99 \\
\hline Khorazm VCHM & 0,87 & 0,97 & 0,94 & 1,01 \\
\hline Guliston IKM & 0,52 & 0,67 & 0,79 & 0,90 \\
\hline Total & $\mathbf{0 , 9 7}$ & $\mathbf{0 , 9 2}$ & $\mathbf{0 , 9 6}$ & $\mathbf{0 , 9 7}$ \\
\hline
\end{tabular}

Relative solvency ratio for the secondary processing industry was positive with a slight decrease in solvency level. Positive kicks of cost reduction policy kept the industry profitable and self-funding, capable of staying sound without subsidies.

\section{Conclusion and Recommendations}

The secondary metallurgic industry is a supplier of high-demand products important for both intermediate and final consumption. Public policy to reduce the cost of primary industrial materials has short- and long-term effect not only in market share capital, but also financial viability and sustainability of enterprises. As shown in Table 4, the volume of working capital is increasing as annual cost reduction policy is prolonged. As for individual working capital requirements experiences the same scenario of growth in different paces. Working capital growth reveals that output volume in the industry is going up and market share, operational income, and saturation objectives are being met. Moreover, it was the first practical application of cost regulation in industrial enterprises which makes costing practices change and adopt other techniques. This evidence proves that in the context of accounting system reforms and transition, cost accounting has to be an integral part of accounting system due to market, cost and profit factors.

\section{References}

- Brogden, H. E., and Taylor, E. K. (1950), The Dollar Criterion - Applying the Cost Accounting Concept to Criterion Construction. Personnel Psychology, No.3. pp.133-154, CrossRef

- Cardinaels, E. (2008), The Interplay between Cost Accounting Knowledge and Presentation Formats in CostBased Decision-Making. Accounting, Organizations and Society. Vol. 33, No. 6. pp. 582-602, CrossRef

- Carmona, S., Ezzamel, M. and Gutierrez, F. (1997), Control and Cost Accounting Practices in the Spanish Royal Tobacco Factory. Accounting, Organizations and Society. Vol. 22, No. 5. pp. 411-446, CrossRef

- Cooper, R. and Kaplan, R. (1988), Measure Costs Right: Make the Right Decisions."Harvard Business ReviewVol. 66, No. 5. pp. 96-103.

- Dearden, J. (1978), Cost Accounting Comes to Service Industries. Harvard Business Review, Vol. 56, No 5. pp. 132-140.

- Gupta, M., Pevzner, M. and Seethamraju, C. (2010), The Implications of Absorption Cost Accounting and Production Decisions for Future Firm Performance and Valuation. Contemporary Accounting Research, 27: 889-922, CrossRef

- Johnson, T. (1972), Early Cost Accounting for Internal Management Control: Lyman Mills in the 1850's. Business History Review, Vol. 46, No. 4. pp. 466-474, CrossRef

- Johnson, T. (1981), Toward a New Understanding of Nineteenth-Century Cost Accounting. The Accounting Review, Vol. 56, No. 3. pp. 510-518.

- Kaplan, R. (1985), Cost Accounting: A Revolution in the Making. Corporate Accounting. 1/1985. pp. $10-16$.

- Lukka, K. and Granlund, M. (1996), Cost Accounting in Finland: Current Practice and Trends of Development. European Accounting Review, Vol. 5, No.1. pp. 1-28, CrossRef

\section{About the Author}

Nodira Abdusalomova is a researcher, a graduate of Tashkent State University of Economics. She is currently conducting her doctoral research in improving cost accounting methods and practices in heavy industry enterprises in Uzbekistan. 